\title{
Isytiqoq Perspektif Aliran Basrah dan Kufah
}

\author{
Mas Tajuddin Ahmad \\ UIN Sunan Ampel Surabaya
}

tajuddinahmad92@gmail.com

- Received: 30.03 .2020 • Accepted: $30.04 .2020 \quad$ • Published online: 10.05 .2020

Abstract: in linguistics, there are studies that focus on making sentences and part of them. Commonly, people call it syntax. No exception in the discipline of Arabic Linguistics, in that discipline there is also a study of syntax, it called Nahwu or Ilmu An Nahwi. The problems in the study of Nahu Science do not stop only at the level of sentences and parts thereof. However, very long before that, there were some schools (madrasah) of critical thingking about the Nahu Science itself. Among the famous schools are Basrah and Kufa. Next will be explained the perspective of the two schools (madrasas) about the Origin of Words Theory (Isytiqoq). The purpose of this study is in order that the reader can find out the concept of isytiqoq according to each schools. This research uses a type of qualitative research methods using various sources of literature related to research. Through this research, we will get results about the theory of isytigoq Basrah which are oriented towards nouns and kufa based on verbs.

Keywords: Isytiqoq, Basrah, Kufah, Arabic

\section{Pendahuluan}

Bahasa merupakan gejala alam yang hanya dapat ditemukan pada manusia. Dapat dikatakan pula bahwa bahasa adalah fenomena rasional sebagai alasan bahwa manusia mempunyai kapabilitas rasional yang berasal dari piranti yang ada pada diri manusia itu sendiri. Dengan piranti tersebut manusia terdorong untuk berbahasa. Bahasa juga merupakan alat perantara manusia dalam menyampaikan maksud, hajat serta tujuannya (Ahmad, 2020). 
Di antara semua bahasa yang ada, Bahasa Arab adalah bahasa yang banyak dipakai dan teliti. Salah satu Ilmu alat yang penting dalam Bahasa Arab adalah Ilmu Nahu selain Ilmu Shorof. Ilmu Nahu adalah kajian yang menitikberatkan pada tata kalimat dan harokat akhir pada tiap kata. Ilmu ini muncul karena munculnya fenomena berbahsa yang disebut dengan Lahn atau sejenis kekeliruan gramatikal berbahasa oleh penutur asli (native speaker). Karena Bahasa Arab sangat erat kaitannya dengan agama maka harus ada penafian atau pemberantasan lahn yang ada. Selain itu, keterbukaan Bahasa Arab untuk berkembang dari aspek kekayaan kosakata dan keilmuan (Safitri \& Sa'dudin, 2019). Hal ini dikarenakan jika terjadi kesalahan berbahasa maka akan terjadi pula kesalahan interpretasi atau penafsiran dalam Bahasa tersebut.

Urgensi dari penelitian ini adalah meskipun telah ada perbedaan yang sangat beragam dari dua madrasah ini, peneliti berusaha memaparkan bahwa perbedaan yang ada tersebut hanyalah pada tataran parsial gramatikal saja tidak menjurus pada maksud dan pemaknaan Bahasa. Ini berarti bahwa jika itu timbul permaslahan itu hanya ada dalam kajian kebahasaan saja bukan pada ranah inti pemaknaan sebagaimana yang ada dalam penelitian berikut. Dalam hal ini peneliti menitikberatkan pada kajian morfemis yang dalam hal ini adalah isytiqoq yang menjadi dasar dari segala dasar pemikiran Ilmu Nahu. Kajian ini memiliki signifikansi tertentu karena kajian asal kata atau isytiqoq ini merupakan akar dari nalar keNahuan pada masing-masing Aliran, yang mana kata dasar adalah unsur pokok yang berperan penting dalam kajian sintaksis itu sendiri.

Dalam kajian sejarah Linguistik Arab dalam hal ini Ilmu Nahu terdapat dua Aliran pemikiran (madrasah) yang mainstream sampai sekarang yakni Madrasah Basrah dan Madrasah Kufah. Keduanya 
merupakan Aliran yang menjadi rujukan bagi penutur, penilti dan pegiat Bahasa Arab. Perbedaan pendapat dua Madrasah ini bahkan termaktub dalam karya Al syaikh al imam kamal al din abi al barakat abdu al rahman ibnu Muhammad bin abi said Al-Anbary al nahwi, Al inshaf fi masail al khilaf baina al nahwiyin al bashriyin wa al kufiyin dan karya Nasyatun nahwi karya Ahmad Thonthowi.

Penelitian ini memiliki perbedaan dari penelitian senada yang pernah ada seperti penelitian di Jurnal Tsaqofah \& Tarikh vol. 3 Januari-Juni 2018 oleh Neldi Hariyanto dari Fakultas Ilmu Budaya Universitas Jambi yang berjudul Beberapa Perbedan Masalah-Masalah Nahu Antara Bashrah dan Kufah dalam Kitab Al-Inshaaf Fi Masaa'il Al-Khilaf Bain Al-Nahwiyyin Al-Basryyin Wa Alkufyyin dan Dalil-Dalil Nahu yang Digunakan dan penelitian yang berjudul Khilâfiyah Nahwiyyah: Dialektika Pemikiran Nahu Basrah dan Kufah dalam Catatan Ibn al-Anbâri oleh Asrina dari Fakultas Syariah IAIN Imam Bonjol Padang dalam Jurnal Miqot Vol. XL No.2 Juli - Desember 2016, di mana penelitian ini memfokuskan pada kajian asal kata (isytiqoq) yang menjadi dasar nalar Nahu pada Aliran Basrah dan Kufah.

\section{Metode}

Metode penelitian merupakan hal yang sangat penting dalam melakukan sebuah penelitian untuk mendapatkan data yang valid serta mempermudah penelitian ini. Oleh karena itu, peneliti memilih jenis metode dan pendekatan yang tepat dalam kajian kali ini. Peneliti menggunakan Metode Penelitian Kualitatif (Library Research) dengan langkah yang akan dijelaskan.

Pertama, Metode Pengumpulan Data, merupakan tahap yang sistematik dan standar dalam memperoleh data yang diperlukan. Dalam hal ini, peneliti menggunakan metode dokumentasi yakni mengumpulkan data-data dengan melihat suatu laporan yang tersedia (Tanzeh, 2009). 
Pada tahap ini peneliti mengumpulkan informasi terkait dari berbagai sumber yang berhubungan dengan pembahasan yang dimaksud. Berikut peneliti menggunakan sumber data dari Al Inshof Fi Masailil Khilaf Bainan Nahwiyyin: Al Bahriyyin Wal Kufiyyin karangan Al Anbariy, Al Madaris An Nahwiyyah karya Syauqi Dhoif dan berbagai karya terkait.

Kedua, Metode Analisis Data, Setelah peneliti memiliki data yang terkait, peneliti menggunakan proses selanjutnya dalam mendapatkan hasil penelitian yang maksimal, yakni melakukan analisa terhadap permasalahan yang ada dan mengaitkan dengan kaidah atau teori yang berkenaan yang keduanya telah ditemukan titik temunya (Mahsun, 2015). Dalam hal ini peneliti melakukan analisis dengan pendekatan linguistik, baik Linguistik Umum maupun Linguistik Arab. Yang mana di dalamnya terdapat pembahasan mengenai asal kata (Isytiqoq).

Ketiga, Pemaparan Analisis Data. Peneliti dalam tahap ini akan memaparkan hasil penelitian yang dilakukan. Setelah melalui metodemetode yang sebelumnya peneliti memaparkan hasil analisisnya dalam bentuk laporan tertulis sebagai hasil dari penelitian yang telah dilakukan.

\section{Hasil dan Pembahasan}

\subsection{Terminologi Isytiqaq}

Kata Isytiqoq (اشتقاق) secara bahasa berarti pengasalan kata (Munawwir, 1997). Dari kata tersebut muncul disiplin kellmuan yang disebut علم الاشتثقاق (etimologi) yang berarti Ilmu yang menyelidiki asal usul kata serta perubahannya dalam bentuk dan maknanya (Purwadarminta, 1996). Isytiqoq juga berarti mengambil bentuk sesuatu dalam setengahnya. Isyiqoqul kalimat minal kalimati itu bermakna mengambil kata yang pertama dari kata yang kedua (Gholayini, 2012). Menurut Abdul Basith Isytiqoq 
adalah suatu kata yang berasal dari kesepakatan orang Arab dan memiliki qiyas sesuai dengan kesepakatan orang Arab serta orang selain Arab tidak dapat menentukan ukuran dari Isytiqoq itu sendiri (Basith, 2015). Dari beberapa definisi yang telah dipaparkan, Isytiqoq dengan kata lain bisa dipahami dengan arti asal kata.

Menurut Ismail Ubaidillah Isytiqoq dimaknai sebagai pengambilan bentuk kata (shighot) dari bentuk kata yang lain. Pengambilan tersebut terjadi karena ada persamaan. Persamaan tersebut baik secara bentuk, makna maupun strukturnya dengan beberapa afiksasi tertentu yang telah ditetapkan (Ubaidillah, 2013).

Mustofa al Gholayini menyatakan Ada tiga macam isytiqoq yakni (Gholayini, 2012) :

a. Isytiqoq Shoghir : mengambil suatu kata dari kata yang lain dengan syarat ada kesinambungan antara dua kata tersebut dalam lafal, makna dan urutan huruf disertai perubahan bentuk kata tersebut, seperti kata

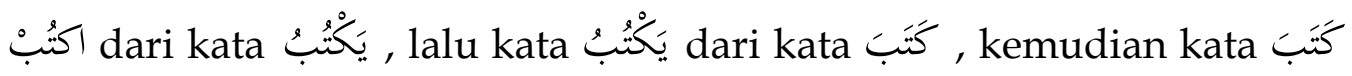
dari kata الكِكِتَابَّة. Bentuk Isytiqoq ini dapat ditemukan di Ilmu Tashrif.

b. Isytiqoq Kabir : mengambil suatu kata dari kata yang lain dengan syarat ada kesinambungan antara dua kata tersebut dalam lafal, makna tetapi tidak pada urutan hurufnya seperti : kata بَذُبَ (memikat/menarik) dan جَبَذَ (menarik/memikat), begitu juga حَمِ (memuji) dan مَدَ (memuji). Isytiqoq Akbar : mengambil suatu kata dari kata yang lain dengan syarat ada kesinambungan dalam makharijul hurufnya seperti : kata نَهَ 
(melengking) dan kata نَ نَقَ (mengeraskan suara). Pada jenis ini terdapat juga kesamaan dalam hal makna.

\subsection{Aliran Basrah dan Kufah}

Perbedaan yang dapat kita fahami antara aliran Nahu Basrah dan aliran Nahu Kufah terletak pada cara memperlakukan data dari bahasa yang digunakan. Aliran Barah Bersifat prespektif, dalam pengertian kaidah-kaidah Nahwu disimpulkan dari gejala-gejala umum dari data bahasa yang ada. Kesimpulan dari gejala itu dijadikan sebagai kaidah. Data- data bahasa yang menyimpang dari gejala-gejala umum ini diperlakukan sebagai 'syadz (tidak dijadikan hujjah). Lain halnya dengan aliran Basrah, aliran Kufah Bersifat deskriptif, dalam pengertian semua data bahasa yang berasal orang Arab yang bahasanya masih dianggap murni, dapat dijadikan acuan dalam membuat kaidah bahasa (Hariyanto, 2018).

Perkembangan Ilmu Nahu menurut Taman Hasan itu terjadi setidaknya karena ada 3 faktor yakni faktor agama, faktor identitas kaum dan faktor politik (Hasan, 2000). Dalam perkembangan Ilmu Nahu terdapat 4 periodisasi sebagaimana pendapat Ahmad Thonthowi, berikut adalah periodisasinya :

1. Periode Penemuan Dan Pembentukan Ilmu Nahu

2. Periode Pertumbuhan Dan Perkembangan Ilmu Nahu

3. Periode Kematangan Dan Feksi Ilmu Nahu

4. Periode Penguatan Ilmu Nahwu

Pada dasarnya embrio Aliran Basrah sudah ada sejak periode penemuan Ilmu Nahu dan embrio Kufah sudah ada sejak periode pertumbuhan Ilmu Nahu. Namun, secara spesifik dan tegas dua Aliran itu 
muncul pada periode ketiga yakni pada periode kematangan (Tantawi, 1997).

Sholah Rawai menyampaikan pendapatnya bahwa Basrah adalah pelopor dalam penemuan Ilmu Nahu. Pada hakikatnya Nahu telah ditemukan dan berkembang dan menjadi sempurna di bumi Basrah dan atas polesan tangan dingin para cendekiawannya. Di sisi lain, Aliran Kufahtelah mengikuti apa yang ada pada Basrah pada sebagian tahapan, padahal Basrah-lah yang lebih dahulu mempeloporinya. Ulama Kufah mulai menggeluti Nahu pada masa sekitar satu abad. Permasalahan ini tidak dipermasalahkan oleh bashrah sama sekali. Namun, sebaiknya harus ada ciri khas dan karakteristik sendiri yang dapat dimiliki Bashrah agar melagealkan posisinya sebagai pelopor dan penemu Ilmu Nahwu (Rawai, 2003).

Perkembangan dan penyebar luasan Ilmu Nahu di Bashrah tidak lepas dari peranan Madrasah al-Bashriyah, sebuah lembaga pendidikan khusus yang dibentuk untuk membina Nahu di Bashrah yang didirikan pada masa Khalil ibn Ahmad al-Farahidi (Tantawi, 1997). Abu Salamah Musa bin Ismail menyebutkan bahwa penyusun pertama Ilmu Nahu adalah Abu al-Aswad al-Du'ali. Sementara yang lain mengatakan Nashr ibn Ashim (Mulloh, 2014). Namun pendapat yang paling shahih adalah Ali ibn Abi Thalib sebagai peletak pertama dasar-dasarnya, kemudian disusun dan dikembangkan oleh Abu al-Aswad (Mulloh, 2014).

Kufah terletak di tepi lembah sungai Eufrat yang terkenal dengan kesuburan tanahnya. Di sebelah Timur berbatasan langsung dengan sungai Eufrat, di sebelah Selatan berbatasan dengan Najf, dan di sebelah Barat dan Utaranya berbatasan langsung dengan padang pasir yang sangat luas dan membentang hingga ke kota Syam (Rawai, 2003). 
Dalam Sejarah, Munculnya aliran Kufah bisa dikatakan sebagai awal mula Khilafiyah Nahwiyah. Seperti yang dijelaskan di atas, Periode Penemuan Dan Pembentukan Ilmu Nahu terjadi di Basrah. Pelopor utamanya adalah Abu al-Aswad al-Dualiy dan ulama-ulama Basrah lainnya. Pada Periode ini, ulama Basrah telah mengkaji ilmu Nahu secara intensif serta mendalam. Keikutsertaan ulama Kufah dalam membangkitkan dan mengembangkan ilmu Nahu serta munculnya kajian Nahu di Kufah pada periode kedua (Periode Pertumbuhan Dan Perkembangan ilmu Nahu) dianggap sebagai sesuatu yang tidak sejalan dengan Basrah (Asrina, 2016).

Madzhab Kufah adalah madzhab Nahu yang dirintis oleh Abu Jafar alRuasiy.Ia menuntut Ilmu di Bashrah kepada ulama-ulama Bashrah. Ia belajar kepada Abu Amr bin al-Ala dan Isa bin Umar al-Tsaqafiy (Rawai, 2003). Para ulama' terdahulu sepakat bahwa madrasah nahwiyah dimulai di Bashrah kemudian berlanjut ke Kufah karena perjalanan Ruasi, Kisai dan Farra' (Mulloh, 2014). Pada dasarnya Nahu yang dikembangkan oleh ulama-ulama Kufah dengan meletakkan kaidah-kaidahnya tidak berbeda dengan apa yang kembangkan Ulama Bashrah. Karena keduanya memang berasal dari satu institusi yang sama yakni Bashrah (Dhaif, 1976).

Sebagian besar para ahli Nahu terdahulu ingin mengadopsi teori Nahu tertentu yang ia kuasai. Namun, dua aliran Nahu yakni Basrah dan kufah justru memberika dampak pada aliran-aliran setelahnya. Keduanya ingin mendirikan aliran nahu masing-masing, yang dari Basrah ingin mendirikan Aliran Nahu Basrah dan yang dari Kufah juga ingin mendirikan aliran Nahu Kufah (Mughni, n.d.).

\subsection{Tokoh Nahwu dalam Basrah dan Kufah}


Setelah mengetahui kronologi berdirinya madzhab bashrah dan Kufah, penulis akan memaparkan beberapa tokoh dari tiap aliran.

\section{Basrah}

a. Al khalil : nama lengkapnya adalah al khalil ahmad al farahidi, lahir tahun $100 \mathrm{H}$ wafat pada tahun $175 \mathrm{H}$ sejak kecil ia aktif dalam berbagai halaqoh ahli hadis, ahli fikih, ahli bahasa dan Nahu. Dia mendalami Ilmu dalam halaqoh-halaqoh itu bersama gurunya isa bin umar abu amru bin al 'alla. Dia gemar membaca hasil terjemahnya khususnya Ilmu mantiq aristoteles begitu juga ia gemar mebaca terjemahannya yang lain seperti Ilmu musik Yunani (Dhaif, 1976).

b. Sibawaih : Nama asli imam Sibawaih adalah Amr bin Usman bin Qanbar, dia terkenal dengan sibawaih yang menunjukkan bahwa dia adalah orang Persia dari bani Haris bin Ka'b, dia lahir di desa Baydha' (بيضاء) lalu keluarganya hijrah ke Basrah dan dia hidup di sana. Dia terus berkembang dengan mengikuti bebagai forum-forum ahli fiqih dan hadis. Dia rutin mengikuti kajian bersasma Hammad bin Salmah bin Dinar ahli hadis terkenal ketika itu (Dhaif, 1976). Al Afkhasy al awsath : dia adalah Abu al hasan Sa'id bin mas'adah, dia oranng Persia seperti Sibawaih. Dia menetap di sana dan belajar kepada sibawaih.

c. Al Mubarrad : nama lengkapnya adalah Muhammad bin yazid Al azdi pimpinan ulama' Nahu Basrah ketika itu. Ada beberapa versi tentang tahun kelahirannya di Basrah. Ada yang mengatakan 210 H, 207 H, 195 H. Dia belajar mendalami Ilmu bahasa pada Ulama Basrah kala itu (Dhaif, 1976). 'Anbasah bin Ma'dan Al Fil Al Mahri. Mendapat laqob al Fil karena ayahnya adalah pemelihara hewan gajah untuk orang- 
orang yang melukakn ibadah haji. Oleh karena itu, ayahnya mendapat laqob tersebut kemudian beralih kepada 'Anbasah (Tantawi, 1997).

\section{Kufah}

a. Al kisai : nama lengkapnya adalah Ali bin Hamzah, dia orang Persia lahir di Kufah pada tahun 119 H. Dia belajar sejak kecil pada sulaiman bin arqom, abu bakr syu'bah bin ayyasy, sufyan bin uyaynah . dia mengikuti halaqoh hamzah bin habib ziyat sampai ia mendapat laqob al kisai dalam majlis itu(Dhaif, 1976).

b. Al farra' : dia orang persia bernama Yahya bin Ziyad bin Abdullah lahir pada tahun $144 \mathrm{H}$ di Kufah dan hidup di sana. Dia belajar sejak masa kecilnya mengikuti halaqoh ulama' seperti Abu bakr bin Ayyasy. Tsa'lab: dia adalah abu abbas ahmad bin yahya ayahnya adala keturunan bani syaiban. Ia lahir di Bahgdad tahun 200 H. Sejak kecil ia diikutkan ayahnya dalam halaqoh menulis dan tahfidz al Quran (Dhaif, 1976).

c. Abu Ja'far Muhammad bin Hasan, tuan dari Muhammad bin ka'b al Qordhi. Mendapat laqob ar Ruasi karena ukuran kepalanya yang besar. Abu Ja'far hidup dan berkembang di Kufah berkelana di Basrah dan berguru kepada Abu Amru bin Al Ala'i dan ulama bashroh angkatan kedua lainnya. Tidak lama kemudian dia kembali Kufah dan belajar Nahu pada pamannya yang bernama Mu'adh. Dari situlah Abu Ja'far menjadi ulama Nahu Kufah yang angkatan pertama dan mengarang kitab yang berjudul Al Faishol fin Nahwi (Tantawi, 1997).

\subsection{Kajian kata pada Linguistik umum dan Arab}

Pada kajian Linguistik Umum dikenal satuan gramatikal dengan istilah kata dan morfem. Para Linguis modern lebih cenderung 
menggunakan istilah morferm. Sedangkan para Linguis tradisional cenderung memilih istilah kata dalam menggunakan satuan gramatikal tersebut.

Term kata sering kita dengar dalam kehidupan sehari-hari. Bahkan secara tidak sadar kita dalam menyampaikan hajat kita melalui komunikasi selalu menggunakan kata sebagai perantaranya hampir disetiap saat dan waktu. Selama ini para linguis mengartikan kata tidak secara paripurna. Namun, ada definisi yang paling mendekati paripurna dan sering dipakai oleh sebagian orang.

Paara Ahli Tata Bahasa atau Tata Bahasawan Tradisional biasanya memberikan pengertian pada kata sesuai dengan arti dan otografi. Mereka mendefinisikan kata adalah satuan bahasa yang memiliki satu pengertian atau kata adalah deretan huruf yang diapit oleh dua buah spasi dan mempunyai satu arti.

Untuk dapat digunakan dalam kalimat, pertuturan tertentu, komunikasi, maka bentuk dasar terutama dalam bahasa fleksi dan aglutunasi harus dibentuk dulu kata yang gramatikal melalui proses afiksasi, reduplikasi, komposisi dan proses pembentukan morfem atau proses morfemis yang lain (Chaer, 2007). Kata atau morfem juga berarti bentuk bahasa yang dapat dipisah-pisahkan menjadi bagian yang lebih kecil. Setelah itu dapat dianalisis lagi menjadi bagian lebih kecil lagi sampai ke bentuk yang jika dipotong lagi tidak bermakna. Oleh karena itu, Al Khuli memberikan pendapatnya mengenai definisi kata atau morfem yaitu ashghoru wahdah lughowiyyah mujarrodah dzatu ma'nan (satuan gramatikal terkecil, otonom serta memiliki makna) (Hidayatullah, 2017).

Dalam Linguistik Umum proses morfemis terdiri dari beberapa hal berikut : afiksasi, reduplikasi, komposisi, konversi, modifikasi internal, suplesi, pemendekan, produktivitas proses morfemis. Lain halnya dengan 
disiplin Linguistik Arab proses morfemis atau pembentukan kata (Binaul kalimat) adalah sebagai berikut : idhofatuz zawaid, murokkab, kalimatul awailiyyah, al ikhtishor al kitabi, al kalimah almanchutah, tarkhim (Hidayatullah, 2017).

\subsection{Isytiqaq Pada Dua Aliran}

Ulama Basrah berpendapat bahwa isytiqoq (asal kata) itu berasal dari masdar atau nomina. Mereka berargumen, bukti bahwa masdar adalah asal fiil yaitu masdar menunjukkan zaman secara tak terbatas. Berbeda dengan fiil yang menunjukkan waktu tertentu, Sebagaimana kemutlakan adalah asal dari keterikatan, begitu pula masdar dan fiil. Penjelasan dari hal tersebut adalah ketika mereka hendak menggunakan masdar, mereka mendapati masdar mencakup semua zaman dan tidak terikat pada salah satu zaman. Jika waktu terjadinya masdar itu belum ditentukan, maka masdar menurunkan kata yang menunjukkan spesialisasi zaman yakni fiil. Oleh karena itu, fiil terdiri dari tiga zaman: lampau, kini dan nanti sebagaimana zaman. Pengkhususan tersebut menunjukkan bahwa masdar adalah asal usul fiil.

Ada ulama Basrah yang berpendapat masdar adalah asal dari fiil. Fiil dengan bentuknya menunjukkan dua hal yaitu kejadian dan waktu kejadian. Sedangkan masdar dengan bentuknya menunjukkan satu hal yaitu kejadian. Seperti yang kita ketahui bersama bahwa yang satu itu adalah asal dari yang dua sebagaimana masdar adalah asal dari fiil (AlAnbari, 2005).

Dalam Kajian Tata Bahasa (gramatika linguistik umum) nomina (isim, dalam kajian Linguistik Arab) atau sering disebut sebagai kata benda itu dapat dicirikan melalui hal, yakni semantis, sintaksis, morfologis. Seseorang dapat mengatakan nomina adalah kata yang mengacu pada 
manusia, binatang, benda dan konsep atau definisi. Dengan itu, morfem seperti guru (أستاذ), kucing (القط), meja (المكتب) dan kebangsaan (الوطنية) adalah nomina (isim). Dari segi sintaksisnya nomina (isim) mempunyai ciri tertentu sebagai mana berikut (Alwi, 2010):

1) Dalam kalimat yang predikatnya verba (al-jumlah al-fi'liyah) nomina lebih condong menduduki posisi sebagai subjek ( $\left.a l-f a^{\prime} i l\right)$, objek (almaf'ul), atau pelengkap (al mutakammilat).

2) Nomina (isim) tidak dapat dinegatifkan dengan kata tidak (لا). Namun, dapat dinegatifkan dengan kata bukan (ليس), seperti : ayah saya seorang guru (أبي أشتاذ) menjadi ayah saya bukan seorang guru (ليس أبي أستاذا).

3) Nomina secara umum bisa diikuti adjektiva (صفة). Baik secara langsung seperti : buku baru (كتاب جديد) atau dengan perantara kata yang (الذي) seperti kitab yang baru (الكتاب الذي هو جديد)

Sedangkan dalam kajian Tata Bahasa Arab (Qowa'idul Lughoh AlArobiyyah), nomina (isim) itu terbagi menjadi dua bagian yakni (Dayyab, Dayyab, Tomum, Umar, \& Muhammad, 2007) :

1) Jamid yaitu nomina (isim) yang tidak dibentuk dari kata lainnya, bisa dikatakan isim itu adalah asal isytiqoq sesuai pendapat ulama Basrah, contohnya : رجل. Isim jamid itu juga ada dua jamid dzat seperti إنسان dan jamid ma'na seperti : فهم yang mana jamid ma'na itu adalah asal kata (isytiqoq) yang akan memunculkan derivasi (turunan kata) 
2) Musytaq yaitu nomina (isim) yang dibentuk dari isim dari nomina (isim) lain seperti : ع علوم kedua adalah derivasi (turunan kata) dari العلم. Bisa dikatakan juga bahwa nomina musyaq ini berasal dari atau merupakan derivasi (turunan kata) dari isim jamid jenis ma'na.

ضرب ضربا) ضlama Kufah berpendapat masdar berasal dari fiil seperti dan قام قياما). Sedangkan ulama Basrah berpendapat fiil berasal dari masdar. Adapula ulama Kufah yang berpendapat : bukti bahwa masdar adalah turunan dari fiil adalah fiil memproduct masdar seperti contoh ضربت ضربا , ضربا dinashabkan oleh ضربت, itu menunjukkan bahwa masdar merupakan product fiil karena posisi amil adalah sebelum posisi ma'mul. Maka masdar pasti adalah turunan dari fiil.

Ada juga ulama Kufah yang berpendapat sesungguhnya masdar disebutkan sebagai ta'kid bagi fiil, dan tidak diragukan lagi posisi muakkad adalah sebelum posisi muakkid. Hal tersebut membuktikan bahwa fiil merupakan asal dan masdar adalah turunan dan juga diperkuat نعم، بئس، (Al-Anbari, 2005).

Dalam Kajian Tata Bahasa (gramatika linguistik umum) verba (fi'il, dalam kajian Linguistik Arab) atau sering disebut sebagai kata kerja itu memiliki ciri-ciri sebagai berikut (Alwi, 2010): 
1) Verba memiliki fungsi utama sebagai predikat (dalam jumlah fi'liyah) sebagai inti predikat dalam kalimat walaupun dapat juga mempunyai fungsi lain. Contoh : pencuri itu lari (بيجري اللصّ)

2) Verba mengandung makna inheren perbuatan (aksi), proses atau keadaan bukan sifat atau kualitas seperti : lari (يجيج) mengandung makna ihern aksi lari, proses lari dan dalam keadaan lari.

3) Verba, khususnya yang bermakna keadaan itu tidak dapat diberi prefiks ter-yang (berarti paling), dalam linguistik Arab disebut tafdhil seperti mati (مات)

4) Secara umum verba tidak dapat digabung dengan kata yang menunjukkan kesangatan (tafdhil), seperti belajar, tidak ada kata lebih belajar, lebih belajar, sangat belajar.

Sedangkan dalam kajian Tata Bahasa Arab (Qowa'idul Lughoh AlArobiyyah), verba (fi'il) adalah kata-kata yang artinya difahami walaupun sendiri (belum masuk dalam kalimat) dan disertai makna waktu terjadinya contoh : قرأ telah membaca يقرأ sedang atau akan membaca, قرأ bacalah (Dayyab et al., 2007).

\section{Simpulan}

Dari kajian yang telah dilakukan peneliti di atas dapat ditarik kesimpulan bahwa kajian Isytiqoq pada dua aliran nahu yakni Basrah dan Kufah memiliki perbedaan yang jelas. Kajian satuan linguistik yang berupa kata (oleh tatabahasawan tradisional) atau morfem (oleh tatabahasawan modern) pada aliran Nahu Basrah Berlandaskan pada pendapat bahwa asal Isytiqoq adalah Nomina. Mereka beralasan bahwa 
nomina (isim) tidak mengandung makna waktu sedangkan verba (fi'il) terikat pada makna yang berkaitan dengan waktu terjadinya kata tersebut.

Sedangkan aliran Nahu Kufah berlandaskan pada pendapat bahwa asal Isytiqoq adalah verba. Mereka memiliki pendapat bahwa nomina (kata benda) adalah derivasi dari fiil. Mereka berorientasi pada kalimat verba (jumlah fi'liyah) yang ada dalam khazanah Linguistik Arab. Dalam kalimat verba ala Linguistik Arab, posisi verba (fi'il) selalu berada di depan sebagai amil dari pada kata nomina yang berposisi sebagai ma'mul. Maka sudah barang tentu jika Nomina (isim) itu adalah derivasi (turunan kata) dari verba $\left(f^{\prime} i l\right)$.

\section{Referensi}

Ahmad, M. T. (2020). Komparasi Konsep Zuhud (Tahapan Tasawuf keenam) Perspektif KH. Hasan Ulama Takeran Magetan dengan Ulama Kontemporer : Kajian Filologi dan Analisis Isi. Yogyakarta: Trussmedia Grafika.

Al-Anbari, A. S. (2005). Al inshaf fi masail al khilaf baina al nahwiyin al bashriyin wa al kufiyin. Kairo: Dar al Thalai'.

Alwi, H. (2010). Tata Bahasa Baku Bahasa Indonesia Edisi ketiga. Jakarta: Balai Pustaka.

Asrina. (2016). Khilafiyah Nahwiyyah :Dialektika Pemikiran Nahu Basrah dan Kufah dalam Catatan Ibn Al Anbari. Miqot, XL(2), 145.

Basith, A. (2015). Al Isytiqoq Bainal Qudama' wal Muhadditsin. Lisanu Ad Dhad, 2(1), 39.

https://doi.org/http://dx.doi.org/10.21111/lisanudhad.v2i1.466

Chaer, A. (2007). Linguistik Umum. Jakarta: Rineka Cipta.

Dayyab, H. B., Dayyab, M. B., Tomum, M., Umar, M. A., \& Muhammad, S.

B. (2007). Kaidah Tata Bahasa Arab Nahwu,Shorof, Balaghah Bayan Ma'ni 
Badi (C. Umam, Trans.). Jakarta: Darul Ulum Press.

Dhaif, S. (1976). Al Madaris Al Nahwiyah. Mesir: Dar Al-Ma'arif.

Gholayini, M. Al. (2012). Jami'ud Durus al Arobiyyah - Edisi 11 Juz 1. Beirut:

Dar Al-Kutub Al-'Ilmiyyah.

Hariyanto, N. (2018). Beberapa Perbedan Masalah-Masalah Nahwu Antara

Bashrah dan Kufah dalam Kitab Al-Inshaaf Fi Masaa'il Al-Khilaf Bain Al-Nahwiyyin Al-Basryyin Wa Alkufyyin dan Dalil- Dalil Nahwu yang Digunakan. Tsaqofah $\mathcal{E}$ Tarikh, 3(1), 1.

Hasan, T. (2000). Al Ushul : Dirosah Ipistimolojiyah lil fikri al lughowi indal arobi. Kairo: Alamul Kutub.

Hidayatullah, M. S. (2017). Cakrawala Linguistik Arab. Jakarta: PT Grasindo.

Mahsun. (2015). Metode Penelitian Bahasa Tahapan Strategi, Metode dan Tekniknya. Jakarta: Raja Garfindon Persada.

Mughni, S. (n.d.). Nasyatun Nahwi Al Araobiy. Al-Qalam, 19(92), 78.

Mulloh, T. (2014). Al Basith fi Ushulin Nahwi wa Madarisihi. Kepanjen:

Dream Litera.

Munawwir, A. W. (1997). Al Munawwir Kamus Arab-Indonesia. Surabaya: Pustaka Progressif.

Purwadarminta. (1996). Kamus Besar Bahasa Indonesia (Edisi Khus). Jakarta: Balai Pustaka.

Rawai, S. (2003). An-Nahu Al- 'Arabiy, Nasyatuhu, Tathowwuruhu, Madarisuhu, Rijaluhu. Kairo: Darul Gharib.

Safitri, E., \& Sa'dudin, I. (2019). Modernisasi Shorf Dalam Al Bahtsu Ashorfi Fid Dirosah Lugowiyah 'Arabiyah Haditsah Karya Nasrin Abdullah Syanuf 'Alwani. Indonesian Journal of Arabic Studies, 1(1). https://doi.org/10.24235/ijas.v1i1.4879

Tantawi, A. (1997). Nasyatun Nahwi wa Tarikh Asyharun Nuhat. Kairo: Dar Al-Ma'arif. 
Mas Tajuddin Ahmad

Tanzeh, A. (2009). Pengantar Metode Penelitian (1st ed.). Yogyakarta: Teras.

Ubaidillah, I. (2013). Kata Serapan Bahasa Asing Dalam Al-Qur'an Dalam Pemikiran At-thobari. Jurnal At-Ta'dib, 8(1), 119-132. 